\title{
Pomegranate and its wild genotypes: Nutraceutical opportunities and challenges
}

\author{
Hamid`, N. S. Thakur, Abhimanyu Thakur, Chetna Sharma, Kanchan Bhatt and Adnan A. Khan* \\ Department of Food Science and Technology, Dr Yashwant Singh Parmar University of Horticulture and Forestry, Nauni, Solan-173230, \\ Himachal Pradesh, India \\ *Division of Nephrology and Hypertension, Department of Medicine, University of California, San Diego, Suite Plaza 1, 4510 Execute Drive, \\ San Diego-92121, USA
}

\section{Article Info}

Article history

Received 21 April 2020

Revised 10 June 2020

Accepted 14 June 2020

Published online 30 June 2020

Keywords

Pomegranate

Peel

Arils

Antioxidants

Nutraceutical

Antimicrobial activity

\begin{abstract}
The great possibilities of bioactive from fruits and their by-products to maintain or improve health, is increasing the interest in finding new products with positive pharmacological effects. Pomegranate and its wild genotypes play great role as a functional food of interest due to its multiple beneficial bioactive components which exerts protective role towards various degenerative diseases. Furthermore, pomegranate and its different parts such as arils, peel, membrane and seeds contain different bioactive compounds such as ascorbic acid, anthocyanins, gallic acid, ellagic acid, punicalagin, quercetin, etc., which have higher bioactivity due to potential to reduce free radical generation and ability to prevent generation of various diseases. Not only commercial cultivars of pomegranate, but different parts of wild genotypes also posseses wide antioxidant potential and antimicrobial activity against food borne pathogens like Staphylococcus aureus, Enterobacter aerogenes, Salmonella typhi, Klebsiella pneumonia, Escherichia coli, etc. In this review, we highlight different studies on the bioactive compounds of pomegranate and its wild genotypes parts specifically linking them through antioxidant activity with increasing therapeutic effects.
\end{abstract}

\section{Introduction}

In the past few years, the natural antioxidants particularly of plant origin has been gaining growing attention as food additives. Antioxidants are generally classified into two types as natural and synthetic antioxidants. The potential toxicity of synthetic antioxidants have given plant products considerable attention toward natural alternatives, which can act as antioxidants to defend against various diseases caused by free radicals. Polyphenols are natural antioxidants present in different concentrations in various parts of pomegranate fruit known as dietary antioxidants and their total dietary intake reported could be as $1 \mathrm{~g} / \mathrm{day}$, which is a lot higher than other phytochemicals (Scalbert et al., 2005). Phenolics are the plants; secondary metabolite possessing an aromatic ring bearing one or more than one hydroxyl groups, together with their functional derivatives. Phenolic compounds originate from one of the most important classes of secondary metabolites in plants and classified on the basis of chemical structure (aromatic ring) as well as the pathway by which they are synthesized (e.g., phenyl propanoid, which produces tannins) (Das and Gezici, 2018). Plants have a large range of phenolic derivatives including simple phenols, benzoic acid derivatives, phenylpropanoids, flavonoids, stilbenes, tannins and lignans. Polyphenols as total dietary intake $(1 \mathrm{~g} /$ day $)$ is

Corresponding author: Dr. Hamid Department of Food Science and Technology, Dr Yashwant Singh Parmar University of Horticulture and Forestry, Nauni, Solan-173230, Himachal Pradesh, India

E-mail: hamidfst6789@gmail.com

Tel.: +91-7018820897
10 times higher than the intake of vitamin $\mathrm{C}$ and 100 times higher that the intakes of vitamin E and carotenoids (Scalbert et al., 2005). In recent years, significant progress has been made in curing the cardiovascular diseases and today it is well established that some polyphenols administered as supplements or with food, improve health condition as indicated by a number of biomarkers closely linked with cardiovascular risk.

Pomegranate fruit comprise of four different parts: the non-edible exocarp and mesocarp (peel) and also the edible endocarp which contains the seed, forming the arils. All fruit parts constitute different compounds in varying concentration (Table 1). The pomegranate fruit should be considered as functional food because it has useful compounds in different parts of the fruit that have functional and medicinal effects (Viuda-Martos et al., 2010). Different parts of pomegranate contains different bioactive polyphenolic compounds such as anthocyanins in arils (delphinidin, cyaniding, pelargonidin3-glucosides and 3,5-diglucosides), hydrolysable tannins in peel (ellagitannins such as punicalagin, punicalin, pedunculagin, granatin A, granatin B) and punicic acid in seeds (conjugated fatty acids), therefore whole fruit extract can be the interesting dietary supplements (Lansky and Newman, 2007). This fruit has also got various medicinal properties due to presence of various bioactive compounds as well as phenolic antioxidants. Extracts of different parts of the fruit seem to have medicinal benefits (Lansky and Newman, 2007). Pomegranate extracts are being used to treat several parasitic and microbial infections. The seed as well as peel extracts of cultivated and wild form of pomegranate were reported to have important anti-bacterial activities against various micro-organisms (Devi et al., 2011) including microbial activities against Staphylococcus aureus, Listeria monocytogens, Escherichia coli and Yersinia 
enterocolitica (AI-Zoreky, 2009). Biological properties of peel (flavedo) are mainly associated with presence of flavonoids and hydrolysable tannins. Polyphenols utilization under permissible limits in products is likely to generate beneficial health effects.
Polyphenols can be used for the development of various nutraceutical/ functional foods as well as for the enrichment of various food products. The present review includes the literature pertaining to these studies under the following heads and sub heads.

Table 1: Nutritional value of pomegranate fruit and its by-products

\begin{tabular}{|c|c|c|c|c|c|}
\hline Parameters & Units/100g & $\begin{array}{c}\text { Pomegranate } \\
\text { (raw) }\end{array}$ & $\begin{array}{c}\text { Pomegranate } \\
\text { juice }\end{array}$ & $\begin{array}{l}\text { Pomegranate } \\
\text { peel powder }\end{array}$ & $\begin{array}{l}\text { Pomegranate } \\
\text { seed powder }\end{array}$ \\
\hline Water & $\mathrm{g}$ & 77.93 & 85.95 & 13.70 & 5.82 \\
\hline Energy & kcal & 83.00 & 54.00 & - & - \\
\hline Protein & $\mathrm{g}$ & 1.67 & 0.15 & 3.10 & 13.66 \\
\hline Total lipids & $\mathrm{g}$ & 1.17 & 0.29 & 1.73 & 29.60 \\
\hline Carbohydrate (by difference) & $\mathrm{g}$ & 18.70 & 13.13 & 80.50 & 13.12 \\
\hline Fiber (total/crude) & $\mathrm{g}$ & 4.00 & 0.10 & 11.22 & 39.36 \\
\hline Total sugars & $\mathrm{g}$ & 13.67 & 12.65 & - & - \\
\hline Calcium $(\mathrm{Ca})$ & $\mathrm{mg}$ & 10.00 & 11.00 & 342.00 & 229.20 \\
\hline Iron $(\mathrm{Fe})$ & $\mathrm{mg}$ & 0.30 & 0.10 & 6.11 & 10.88 \\
\hline Magnesium (Mg) & $\mathrm{mg}$ & 12.00 & 7.00 & 56.00 & - \\
\hline Phosphorus (P) & $\mathrm{mg}$ & 36.00 & 11.00 & 120.00 & 481.10 \\
\hline Potassium (K) & $\mathrm{mg}$ & 236.00 & 214.00 & 150.00 & 434.40 \\
\hline Sodium (Na) & $\mathrm{mg}$ & 3.00 & 9.00 & 68.00 & 33.03 \\
\hline Zinc (Zn) & $\mathrm{mg}$ & 0.35 & 0.09 & 1.08 & 5.54 \\
\hline Copper $(\mathrm{Cu})$ & $\mathrm{mg}$ & 0.16 & 0.02 & 0.65 & 3.82 \\
\hline Selenium (Se) & $\mathrm{mg}$ & 0.0005 & 0.0003 & 1.07 & 0.23 \\
\hline Manganese (Mn) & $\mathrm{mg}$ & 0.12 & 0.10 & 0.86 & 2.26 \\
\hline Vitamin A (ERA) & $\mathrm{mg}$ & - & - & 0.181 & 0.089 \\
\hline Thiamin $\left(B_{1}\right)$ & $\mathrm{mg}$ & 0.07 & 0.02 & 0.141 & 0.930 \\
\hline Riboflavin $\left(\mathrm{B}_{2}\right)$ & $\mathrm{mg}$ & 0.05 & 0.02 & 0.09 & 0.146 \\
\hline Niacin $\left(B_{3}\right)$ & $\mathrm{mg}$ & 0.29 & 0.23 & - & - \\
\hline Pantothenic acid $\left(\mathrm{B}_{5}\right)$ & $\mathrm{mg}$ & 0.38 & 0.29 & - & - \\
\hline Pyridoxine $\left(\mathrm{B}_{6}\right)$ & $\mathrm{mg}$ & 0.08 & 0.04 & - & - \\
\hline Folate $\left(B_{9}\right.$ DFE $)$ & $\mu \mathrm{g}$ & 38.00 & 24.00 & - & - \\
\hline Vitamin C (ascorbic acid) & $\mathrm{mg}$ & 10.20 & 0.10 & 13.26 & 3.02 \\
\hline Vitamin E ( $\alpha$-tocopherol) & $\mathrm{mg}$ & 0.60 & 0.38 & 413 & 1.35 \\
\hline Fatty acids (total saturated) & $\mathrm{g}$ & 0.12 & 0.08 & 23.04 & 8.1 (seed oil) \\
\hline Fatty acids (total monounsaturated) & $\mathrm{g}$ & 0.09 & 0.06 & 20.76 & 8.6 (seed oil) \\
\hline Fatty acids (total polyunsaturated) & $\mathrm{g}$ & 0.08 & 0.05 & 56.20 & 82.0 (seed oil) \\
\hline
\end{tabular}

DFE: Dietary folate equivalent; ERA: Equivalent to retinol activity

Source: USDA (2020); Omer et al. (2019); Rowayshed et al. (2013).

\section{Antioxidant potential}

Generally, plants and plant products are rich sources of natural antioxidants including vitamins (ascorbic acid, vitamin A and $\alpha$-tocopherols), carotenoids and phenolic compounds. The recent interest in the bioactivity of the flavonoids from plant sources is due to the potential health benefits of the phenolic compounds as important dietary antioxidants. They exist in the form of vitamins, minerals, anthocyanins, phenols and tannins in various foods including wild pomegranate as well in cultivated pomegranate (Table 2). Reactive oxygen species (ROS) toxic effects depend on its ability to destroy important and sensitive biological substrates, such as DNA, RNA, proteins, and membrane lipids. ROS include superoxide radicals, lipoperoxides, hydrogen peroxide and hydroxyl free radicals. Pomegranate peel's antioxidant function is related to its phenolic compounds in the form of anthocyanins, gallotannins, ellagitannins, gallagy esters, hydroxybenzoic acids, hydroxycinnamic acids, and dihydroflavonol. Pomegranates have the highest concentration of punicalagin and studies have shown that punicalagin has the properties of antioxidants, antifungal and antibacterial. Pomegranate punicalagin alpha and beta forms are polyphenolic hydrolysable tannins, and 2,3-(S)-hexahydro xydiphenoyl-4,6-(S, S)-gallagyl-D-glucose isomers (Ismail et al., 2012). Ascorbic acid is an antioxidant naturally found in fruits and vegetables which play an important role in the prevention of various diseases. Ascorbic acid content in the range of 9.23 to $22.48 \mathrm{mg} / 100$ $\mathrm{g}$ has been observed in various wild pomegranate genotypes grown in Kashmir valley and in HP (Wani et al., 2014; Thakur et al., 2018). Pande and Akoh (2009) have reported ascorbic acid content as 1.4 to 4.2 and 20.3 to $37.3 \mathrm{mg} / 100 \mathrm{~g}(\mathrm{FW})$ in seeds and peels of six pomegranate cultivars. However, Barros et al. (2014) have reported vitamin $C$ content in pomegranate peel as $0.21 \pm 0.1 \mathrm{mg} / \mathrm{g}$ (ascorbic acid equivalent/g of freeze dried peel). Sorour et al. (2014) have reported ascorbic acid content in fresh pomegranate fruit peel and seeds as 1.44 and $0.16 \mathrm{mg} / 100 \mathrm{~g}$, respectively. In Ganesh and Mridula cultivars, Hota and Dahiya (2017) reported ascorbic acid content as 10.52 and $13.81 \mathrm{mg} / 100 \mathrm{~g}$, respectively. 
Table 2: Range of various phytoconstituents in different parts of pomegranate fruit

\begin{tabular}{|c|c|c|c|c|}
\hline Type & Fruit part & \multicolumn{2}{|c|}{ Ascorbic acid $(\mathrm{mg} / 100 \mathrm{~g})$} & Activity/Health effects \\
\hline Wild & \multirow{2}{*}{ Arils } & \multicolumn{2}{|c|}{$10.52-13.81$} & \multirow{3}{*}{$\begin{array}{l}\text {-Acts as antioxidant } \\
\text { - Can remove superoxide and hydroxyl radicals } \\
\text { - Essential for the biosynthesis of collagen } \\
\text { - Natural antioxidant, potent reducing agent that efficiently } \\
\text { quenches potentially damaging free radicals produced by } \\
\text { normal metabolic respiration of the body. Prevent initiation } \\
\text { and progression of several chronic and acute diseases }\end{array}$} \\
\hline Cultivated & & \multicolumn{2}{|c|}{$1.40-29.41$} & \\
\hline Cultivated & Flavedo & \multicolumn{2}{|c|}{$1.44-37.30$} & \\
\hline \multirow[t]{2}{*}{ Wild } & \multirow{3}{*}{ Arils } & \multicolumn{2}{|c|}{ Anthocyanins (mg/100 g) } & \multirow{3}{*}{$\begin{array}{l}\text {-Water soluble pigment responsible for red color of arils acts as } \\
\text { free radicals scavenger } \\
\text {-Dietary antioxidants that help prevent neuronal diseases, } \\
\text { cardiovascular diseases, cancer, diabetes, inflammation, and } \\
\text { many other diseases }\end{array}$} \\
\hline & & \multicolumn{2}{|c|}{$9.65-22.15$} & \\
\hline Cultivated & & \multicolumn{2}{|c|}{$3.40-180.70$} & \\
\hline \multirow{2}{*}{ Wild } & \multirow{2}{*}{ Arils } & \multicolumn{2}{|c|}{ Total phenols (mgGAE /100 g) } & \multirow{13}{*}{$\begin{array}{l}\text {-Polyphenols are reducing agents and together with other dietary } \\
\text { reducing agents, such as vitamin C, vitamin E and carotenoids, } \\
\text { they protect the body's tissues against oxidative stress. } \\
\text {-Flavonoids protect cell constituents against oxidative damage } \\
\text { through scavenging of free radicals. } \\
\text { - The bioactivity exerted by these compounds has been } \\
\text { associated with reduced risk of severe diseases. }\end{array}$} \\
\hline & & \multicolumn{2}{|c|}{$84.64-103.97$} & \\
\hline \multirow[t]{4}{*}{ Cultivated } & Pulp & \multicolumn{2}{|c|}{$164.4-2380.0$} & \\
\hline & Flavedo & \multicolumn{2}{|c|}{$18.0-5990.0$} & \\
\hline & Seeds & \multicolumn{2}{|c|}{$2.0-89.2$} & \\
\hline & Albedo & \multicolumn{2}{|c|}{$177.4-0-2149.00$} & \\
\hline \multirow{3}{*}{ Wild } & \multirow{3}{*}{ Arils } & \multicolumn{2}{|c|}{ Total flavonoids $(/ 100 \mathrm{~g})$} & \\
\hline & & (mg QuE) & (mg CE/RE) & \\
\hline & & $31.75-41.89$ & - & \\
\hline \multirow[t]{4}{*}{ Cultivated } & Pulp/juice & $5.4-99.20$ & $84.0-458.0$ & \\
\hline & Flavedo & $1.2-821.0$ & 5640 & \\
\hline & Seeds & $1.50-11.2$ & $760-6460$ & \\
\hline & Albedo & $162.0-706.0$ & - & \\
\hline
\end{tabular}

GAE: Gallic acid equivalent; $\mathrm{QuE}=$ Quercetin equivalent, $\mathrm{CE}=$ Catechin equivalent, $\mathrm{RE}=\mathrm{Rutin}$ equivalent.

Sources: Gill et al. (2000); Scalbert et al. (2005); Pande and Akoh, (2009); Ardekani et al. (2011); Thakur et al. (2011); Shiban et al. (2012); Zaouay et al. (2012); AI-Rawahi et al. (2013); Mansour et al. (2013); Rowayshed et al. (2013); Ali et al. (2014); Barros et al. (2014); Sorour et al. (2014); Mphahlele et al. (2014); Wani et al. (2014); Fernandes et al. (2015); Li et al. (2015); Ambigaipalan et al. (2016); Li et al. (2016); Asadi- Gharneh et al. (2017); Hota and Dahiya (2017); Derakhshan et al. (2018); Thakur et al. (2018)

\subsection{Anthocyanins}

Anthocyanins are a sub-class of flavonoids that are responsible for the brilliant red, blue and purple colour of most of the fruits and vegetables. These occur in various chemical forms, both colored and uncolored, according to $\mathrm{pH}$. Though they are extremely unstable in the aglycone type (anthocyanidins), once they are in plants, they are resistant to conditions of light, $\mathrm{pH}$ and oxidation which are likely to degrade them. Glycosylation, usually with a glucose at position 3, and esterification with various organic acids (citric and malic acids) and phenolic acids avoid degradation. In addition, the development of complexes with other flavonoids (copigmentation) helps to stabilize anthocyanins (Manach et al., 2004). Gill et al. (2000) have reported $30.60 \mathrm{mg} / 100 \mathrm{ml}$ of total anthocyanins content in fresh arils of Wonderful cultivar. They further reported that anthocyanins were composed of delphinidin-3-5-diglucoside, cyanidin-3,5-diglucoside, delphinidin-3-glucoside, cyanidin-3diglucoside and pelargonidin-3-glucoside with the concentrations of $4.29,5.30,7.60,12.83$ and $0.59 \mathrm{mg} / 100 \mathrm{ml}$, respectively. Zaouay et al. (2012) and Asadi-Gharneh et al. (2017) have proclaimed the wide range of anthocyanins content from 5.40 to $180.70 \mathrm{mg}$ per $100 \mathrm{~g}$ in different pomegranate Persian and cultivars grown in Tunusia. However, anthocyanins content of wild pomegranate fruits ranging from 9.65 to $22.15 \mathrm{mg} / 100 \mathrm{~g}$ from different locations of Himachal Pradesh (HP) and Kashmir has been observed by Wani et al. (2014) and Thakur et al. (2018).

\subsection{Total phenols}

Phenolic compounds are those that have a minimum of one aromatic ring connected to one or more hydroxyl groups. There are several thousands of polyphenolic compounds that occur as secondary metabolites of plants. Phenolic compounds such as flavonoids, phenolic acids and tannins are considered to be major contributors to the antioxidant capacity of plants. Polyphenols antioxidant activity is characterized by their phenolic structure and the ability to delocalize unpaired electrons has the strongest activity (Croft, 2006). These antioxidants also possess diverse biological activities, such as anti-inflammatory, anti-atherosclerotic and anti-carcinogenic activities as reported in literature. These activities may be related 
to their antioxidant activity. Two types of major polyphenolic compounds are present in pomegranate fruit extract are anthocyanins (delphinidin, cyanidin and pelargonidin), which contribute fruit and juice its color and hydrolysable tannins (punicalin, pedunculagin, punicalagin, gallagic and ellagic acid esters of glucose), which account for 92 per cent of the antioxidant activity of the whole fruit (Gill et al., 2000). Total phenols content as 84.64 to $116.30 \mathrm{mg} \mathrm{GAE} / 100 \mathrm{~g}$ in wild pomegranate fruit arils from different locations of HP has been reported in previous studies (Thakur et al., 2011; Thakur et al., 2018). Different workers have reported total phenols content in different cultivated pomegranate cultivars in the broad range from 164.4-2380.0 mg GAE/100 g (Pande and Akoh, 2009; Derakhshan et al., 2018). Peel of this fruit is rich source of various polyphenolic compounds. Rowayshed et al. (2013) have reported total polyphenolic content of pomegranate peel powder as 1.40 per cent on dry weight basis. They further reported that polyphenol fractions in pomegranate peel powder contain catechins $(868.4 \mathrm{mg} / 100 \mathrm{~g})$, gallic acid $(125.8 \mathrm{mg} / 100 \mathrm{~g})$, caffeic acid $(60.46 \mathrm{mg} / 100 \mathrm{~g})$, ellagic acid $(44.19 \mathrm{mg} / 100 \mathrm{~g}), \mathrm{p}$-coumaric $(17.64$ $\mathrm{mg} / 100 \mathrm{~g})$ and resorcinol $(12.50 \mathrm{mg} / 100 \mathrm{~g})$. A very high total phenols content as $5990 \mathrm{mg} \mathrm{GAE} / 100 \mathrm{~g}$ in fresh pomegranate peel has also been reported by AI-Rawahi et al. (2013), whereas, Fernandes et al. (2015) have reported total phenols content as 20.39 to $33.87 \mathrm{mg}$ GAE/g in peel and 16.76 to $21.49 \mathrm{mg} \mathrm{GAE} / \mathrm{g}$ in capillary membrane (pellicle) of pomegranate fruit. Li et al. (2016) have reported total phenolic fraction in peel of five pomegranate cultivars as gallic acid ( 0.18 to $0.41 \mathrm{mg} / \mathrm{g} \mathrm{dw})$ and ellagic acid (2.68 to $7.07 \mathrm{mg} / \mathrm{g} \mathrm{dw})$. Ambigaipalan et al. (2016) have reported total phenolic content as $21.18 \mathrm{mg} \mathrm{GAE} / \mathrm{g}$ in divider membrane, $17.74 \mathrm{mg} \mathrm{GAE} / \mathrm{g}$ in mesocarp and $9.38 \mathrm{mg} \mathrm{GAE} / \mathrm{g}$ in outer layer of peel of pomegranate fruit. Pande and Akoh (2009) have reported total polyphenolic content in seeds of pomegranate fruits as $89.2 \mathrm{mg} \mathrm{GAE} / 100 \mathrm{~g}(\mathrm{FW})$. However, Li et al. (2016) have reported total phenolic fraction as gallic acid ( 0.02 to $0.03 \mathrm{mg} / \mathrm{g} \mathrm{dw}$ ) and ellagic acid $(0.05$ to $0.02 \mathrm{mg} / \mathrm{g} \mathrm{dw})$ in seeds of five pomegranate cultivars.

\subsection{Total flavonoids}

Flavonoids are the most abundant plant polyphenols occurring in fruits with a strong antioxidant activity. Flavonoids also consits water soluble pigments that are present in the plant cell vacuoles. They have basic structural unit $\mathrm{C}_{6}-\mathrm{C}_{3}-\mathrm{C}_{6}$, comprises two phenyl rings together with one heterocyclic ring fused. They are divided into 6 subclasses: flavonols, flavones, isoflavones, flavanones, anthocyanidins, and flavanols (catechins and proanthocyanidins) (Manach et al., 2004). These are reported to be active against various bacterial disease, oxidation, viral diseases and algesia. These are widely distributed as essential secondary metabolites in plants and have many health benefits due to active against free radicals (Das and Gezici, 2018; Nooreen et al., 2018). Pande and Akoh (2009) have reported individual flavonoid content as 92.1 to $99.2 \mathrm{mg} / 100 \mathrm{~g}$ (FW) quercetin equivalent in pulp of 6 pomegranate cultivars, whereas, Ardekani et al. (2011) have reported total flavonoids content ranging from 0.84 to $2.14 \mathrm{mg} \mathrm{CE} / \mathrm{g}$ in pulp extract of nine Persian pomegranate cultivars. Mphahlele et al. (2014) have reported a little higher amount of total flavonoids content $(3.35$ to $4.58 \mathrm{mg}$ $\mathrm{CE} / \mathrm{ml}$ ) in juice extracted from Wonderful $\mathrm{cv}$. of pomegranate fruit. Thakur et al. (2018) have reported total flavonoids content of wild pomegranate fruits ranging from 31.75 to $41.89 \mathrm{mg} \mathrm{QuE} / 100 \mathrm{~g}$ from
4 different locations of HP. A very low amount of flavonoids content as 0.054 to $0.335 \mathrm{mg} \mathrm{QuE} / \mathrm{ml}$ has been reported in ten Chinese pomegranate cultivars by Li et al. (2015). Pande and Akoh (2009) have reported individual phenolic content as 66.7 to 77.1 and 10.6 to $11.2 \mathrm{mg} \mathrm{QuE} / 100 \mathrm{~g}(\mathrm{FW})$ in peel and seeds of 6 pomegranate cultivars. Total flavonoids as $56.40 \pm 2.70 \mathrm{mg} \mathrm{RE} / \mathrm{g}$ in methanolic extract of pomegranate peel have been reported by Shiban et al. (2012). Total flavonoids in pomegranate peel as 1.2 to $2.9 \mathrm{mg} \mathrm{QuE} /$ $100 \mathrm{~g}(\mathrm{dw})$ have been reported by Mansour et al. (2013), whereas, Fernandes et al. (2015) have reported range of total flavonoids content as 492.0 to $821.0 \mathrm{mg} \mathrm{QuE} / 100 \mathrm{~g}$ in peel and 162.0 to 706.0 $\mathrm{mg} \mathrm{QuE} / 100 \mathrm{~g}$ in capillary membrane (pellicle) of pomegranate fruit. Ali et al. (2014) have reported higher total flavonoids content in pomegranate seed as $64.6 \pm 0.68$ (methanol extract) and 7.60 \pm 0.25 $\mathrm{mg} \mathrm{RE} / \mathrm{g}$ (ethyl acetate extract on dry weight basis). Fernandes et al. (2015) have reported range of total flavonoids content as 1.50 to $2.90 \mathrm{mg} \mathrm{QuE} / 100 \mathrm{~g}$ in seeds of pomegranate fruit.

\subsection{Antioxidant properties}

The disease prevention mechanism is attributed to the antioxidant properties of polyphenolic compounds. So far no literature on antioxidant activity of wild pomegranate fruit has been reported, however, in commercial cultivars it has been reported widely (Table 3 ).

\subsubsection{DPPH (2, 2-Diphenyl-1-picrylhydrazyl) radical scavenging activity}

DPPH (2,2- Diphenyl-1-picrylhdrazyl) radical is one of the few stable organic nitrogen radicals, which bears a deep purple colour. This assay is based on the measurement of the reducing ability of antioxidants toward DPPH. Antioxidant assays are based on measurement of loss of DPPH colour at $515 \mathrm{~nm}$ after reaction with test compound (Prior et al., 2005). DPPH antioxidant activity of wild pomegranate fruits ranging from 32.11- 40.72 per cent from different locations have been reported by various researchers (Thakur et al., 2018). Whereas, Akhavan et al. (2015) have also reported lower range of antioxidant activity as 18.8 to 46.8 per cent in pomegranate juices from 10 different Iranian cultivars. Kulkarni (2005) has reported antioxidant activity of pomegranate pith and capillary membrane as $3.35 \pm 0.04$ per cent, $92.1 \pm 0.32$ per cent and $94.5 \pm 0.02$ per cent in chloroform, ethyl acetate and methanol extracts, respectively. Orak et al. (2012) have reported DPPH free radical scavenging activity of pomegranate peel extract as 77.02 to 86.36 per cent and in seed extract as 12.07 to 12.65 per cent. A high antioxidant activity in fresh pomegranate fruit peel and seeds as 90.22 and 91.83 per cent, respectively has been observed by Sorour et al. (2014). However, Derakhshan et al. (2018) have reported antioxidant activity in different parts of pomegranate fruit ranging from 45 to 58 per cent and 26 to 54 per cent in ethanolic extract of peel and seeds, respectively.

\subsubsection{FRAP (Ferric reducing anti-oxidant power) assay}

FRAP measure the reducing capability based upon ferric ion and assay is based on the rapid reduction in ferric-tripyridyltriazine $\left(\mathrm{Fe}^{3+}\right.$ TPTZ) by antioxidants present in the samples forming ferroustripyridyltriazine ( $\mathrm{Fe}^{2+} \mathrm{TPTZ}$ ), a blue-colored product (Benzie and Strain, 1996). The reaction detects compounds with redox potentials $<0.7 \mathrm{~V}$ (the redox potential of $\mathrm{Fe}^{3+}-\mathrm{TPTZ}$ ), so FRAP is a reasonable screen for the ability to maintain redox status in cells and tissues. 
Table 3: Range of various antioxidant properties of different parts of pomegranate fruit

\begin{tabular}{|c|c|c|c|}
\hline Type of fruit & Fruit part & Antioxidant activity (\%) & Mechanism \\
\hline Wild pomegranate & Arils & $32.11-40.72$ & \multirow{5}{*}{$\begin{array}{l}\text {-DPPH radical is one of the few stable organic nitrogen } \\
\text { radicals, which bears a deep purple colour. } \\
\text { - This assay is based on the measurement of the reducing } \\
\text { ability of antioxidants toward DPPH. } \\
\text { - Antioxidant assays is based on measurement of DPPH colour } \\
\text { loss at } 515 \mathrm{~nm} \text { after reaction with test compound. }\end{array}$} \\
\hline \multirow{4}{*}{$\begin{array}{l}\text { Cultivated } \\
\text { pomegranate }\end{array}$} & Juice & $18.8-46.80$ & \\
\hline & Flavedo & $45.0-90.22$ & \\
\hline & Albedo & $3.35-94.50$ & \\
\hline & Seeds & $12.07-91.83$ & \\
\hline \multirow{2}{*}{$\begin{array}{l}\text { Wild } \\
\text { pomegranate }\end{array}$} & \multirow{2}{*}{ Arils } & FRAP $\left(\mu \mathrm{mol} \mathrm{Fe}^{2+} / 100 \mathrm{~g}\right)$ & \multirow{5}{*}{$\begin{array}{l}\text {-FRAP measure the reducing capability based on the rapid } \\
\text { reduction in ferric-tripyridyltriazine ( } \mathrm{F}^{3+} \mathrm{TPTZ} \text { ) by } \\
\text { antioxidants present in the samples forming ferrous- } \\
\text { tripyridyltriazine ( } \mathrm{Fe}^{2+} \mathrm{TPTZ} \text { ), a blue-colored product. } \\
\text {-FRAP is a reasonable screen for the ability to maintain } \\
\text { redox status in cells and tissues. Reducing power appears to } \\
\text { be related to the level of hydroxylation and extent of } \\
\text { conjugation in polyphenols. }\end{array}$} \\
\hline & & $19.37-27.65$ & \\
\hline \multirow{3}{*}{$\begin{array}{l}\text { Cultivated } \\
\text { pomegranate }\end{array}$} & Juice & $13.6-46782.0$ & \\
\hline & Flavedo & $82.11-282.666$ & \\
\hline & Seeds & $0.72-20.70$ & \\
\hline \multirow{2}{*}{$\begin{array}{l}\text { Wild } \\
\text { pomegranate }\end{array}$} & \multirow{2}{*}{ Arils } & Metal chelating activity (\%) & \multirow{5}{*}{$\begin{array}{l}\text {-It measures the chelating activity of ferrous ions by extracts } \\
\text { through inhibition percentage of ferrozine- } \mathrm{Fe}^{2+} \text { complex } \\
\text { formation directly. } \\
\text { - Monitoring of the ferrous ion was achieved by calculating } \\
\text { the formation of a red ferrous ion-ferrozine complex at } \\
562 \mathrm{~nm} \text {. Color reduction calculation provides an estimation } \\
\text { of the coexisting chelator's binding capability. }\end{array}$} \\
\hline & & $10.45-12.57$ & \\
\hline \multirow{3}{*}{ Cultivated } & Juice & $13.26-38.23$ & \\
\hline & Flavedo & $10.86-68.55$ & \\
\hline & Seeds & $2.10-12.06$ & \\
\hline \multirow{2}{*}{$\begin{array}{l}\text { Wild } \\
\text { pomegranate }\end{array}$} & \multirow{2}{*}{ Arils } & Reducing power (OD at $700 \mathrm{~nm}$ ) & \multirow{5}{*}{$\begin{array}{l}\text { - It is related to its electron transfer ability. } \\
\text { - Substances with reduction potential react with potassium } \\
\text { ferricyanide forming potassium ferrocyanide that reacts } \\
\text { further with } \mathrm{FeCl}_{3} \text { to form an intense prussian blue complex } \\
\text { with maximum absorption at } 700 \mathrm{~nm} \text { and increased } \\
\text { absorption at } 700 \mathrm{~nm} \text { indicate the reduced power. }\end{array}$} \\
\hline & & $0.256-0.365$ & \\
\hline \multirow{3}{*}{ Cultivated } & Juice & $0.090-0.290$ & \\
\hline & Flavedo & $1.01-1.89$ & \\
\hline & Seeds & $0.16-0.45$ & \\
\hline
\end{tabular}

Source: Guo et al. (2003); Kulkarni (2005); Prior et al. (2005); Hajimahmoodi et al. (2008); Ardekani et al. (2011); Orak et al. (2012); Sorour et al. (2014); Akhavan et al. (2015); Anahita et al. (2015); Basiri (2015); Gupta, (2015), Aloqbi et al. (2016); Thakur et al. (2018); Derakhshan et al. (2018)

Reducing power appears to be related to the degree of hydroxylation and extent of conjugation in polyphenols. FRAP mechanism is totally electron transfer conducted in acidic $\mathrm{pH}$ and rely on hypothesis that redox reactions proceed so rapidly that all reactions are complete within 4 and 6 minutes. Fast reacting phenols that bind the iron or breakdown to compounds with lower or different reactivity are best analyzed with short reaction time (Prior et al., 2005). Thakur et al. (2018) have reported antioxidant activity as per ferric reducing antioxidant power of wild pomegranate fruits ranged from 19.37 to $27.65 \mu \mathrm{M} \mathrm{Fe}^{2+} / 100 \mathrm{~g}$ from 4 different locations of HP. Antioxidant activity as 279.33 to $467.82 \mathrm{micromol} \mathrm{Fe}^{2+} / \mathrm{g}$ (FRAP value) in pulp of nine Persian pomegranate cultivars has been reported by Ardekani et al. (2011). Akhavan et al. (2015) have also reported FRAP in pomegranate aril juice from 10 different Iranian cultivars as 13.6 to $25.9 \mathrm{mmol} \mathrm{Fe} \mathrm{Fe}^{2+} / 100 \mathrm{ml}$. However, Guo et al. (2003) have reported antioxidant activity of pomegranate pulp, peel and seeds as $3.10 \pm 0.12,82.11 \pm 4.01$ and $0.72 \pm 0.05 \mathrm{~m} \mathrm{~mol} /$ $100 \mathrm{~g}$ as ferric reducing power (on wet weight basis). Hajimahmoodi et al. (2008) have reported the antioxidant activity of ten Persian pomegranate cultivar hydroextracts. They further reported the highest FRAP value in pulp and peel in Sour alac (143.9 \pm 4.2 micromol/g hydro extract) and Sweet white peel $(2826.66 \pm 252.75$ micromol/g hydro extract) cultivars. Anahita et al. (2015) have also reported ferric reducing antioxidant power of pomegranate juice, seeds and juice with seeds as $32 \pm 5.1,20 \pm 2.8$, and $47 \pm 5.5 \mathrm{mmol}$ $\mathrm{Fe}^{2+} / 1$, respectively. Basiri (2015) has also reported ferric reducing antioxidant power of pomegranate seeds as 20.70, 4.07 and 2.22 $\mu \mathrm{mol} \mathrm{Fe} e^{2+} / 100 \mathrm{~g}$ in water extract, acetone extract and ethyl acetate extract of seeds, respectively.

\subsubsection{Metal chelating activity}

It measures the chelating activity of ferrous ions by extracts. The inhibition percentage of ferrozine- $\mathrm{Fe}^{2+}$ complex formation is measured spectrophotometrically at $562 \mathrm{~nm}$ (Orak et al., 2012 and Gupta, 2015). Orak et al. (2012) have reported metal chelation capacity of extracts of different parts of four pomegranate cultivars ranging from 13.26 to 38.23 per cent (in juice extracts), 2.10 to 12.06 per cent (in seed extracts) and 10.86 to 68.55 per cent (in peel extracts). They further reported that mean value of metal chelating capacity of different extracts was 37.22 per cent in peel extract, 7.15 per cent in seed extract and 16.19 per cent in juice extract of four pomegranate cultivars. Metal chelating activity as 14.00 per cent in Spanish pomegranate cultivars has been observed by Aloqbi et al. (2016). Thakur et al. (2018) have reported metal chelating activity of wild pomegranate fruits ranging from 10.45 to 12.57 per cent among 4 different locations of HP. 


\subsubsection{Reducing power}

The reducing power of a compound is related to its electron transfer ability and may therefore, serve as a significant indicator of its potential antioxidant activity. The increased absorbance of reaction mixture at $700 \mathrm{~nm}$ indicates the reduced power (Orak et al., 2012). Substances having a reduction potential react with potassium ferricyanide forming potassium ferrocyanide which further reacts with $\mathrm{FeCl}_{3}$ to form an intense prussian blue complex having maximum absorbance at $700 \mathrm{~nm}$ (Gupta, 2015). The reducing power of a compound is related to its electron transfer ability and may therefore serve as a significant indicator of its potential antioxidant activity. Thakur et al. (2018) have reported reducing power of wild pomegranate fruits varying from 0.256 to 0.365 (absorbance at 700 $\mathrm{nm}$ ) from 4 different locations of HP. However, Orak et al. (2012) have reported reducing power of different parts of four cultivars as 1.01 to 1.89 (in peel extracts), 0.10 to 0.19 (in juice extracts) and 0.16 to 0.45 (in seed extracts), whereas, by taking the mean values they further reported that the reducing power of peel extract is 4.70 fold higher than seed extract and 10.50 fold higher than juice extract. A wide range of reducing power ranging from 0.090 to 0.290 (in terms of absorbance at $700 \mathrm{~nm}$ ) has been reported in various Spanish pomegranate cultivars (Aloqbi et al., 2016).

\section{Traditional utilization}

Pomegranate fruit plant is widely used in curing various ailments. The evidence of these are also mentioned in various texts as use in traditional medicines including the traditional Indian medicine as Ayurveda, Unani and Greek documents for the cure of numerous diseases and ailments as vermifuge bactericide, stimulant, hair dye, to improve the symptoms of respiratory illness (asthma, bronchitis) and inflammation, fever, bleeding disorders (Reddy et al., 2007). The hydroethanolic extract of the whole fruit in the traditional Cuban medicine, was also used to treat respiratory diseases. The parts of pomegranate as peel have also been used since ancient times in the Middle East as textiles colorant because of peel high phenolic and tannin contents (Li et al., 2006). Aqueous pomegranate peel extract (dried peel decocted in water) is obtained by traditionally is used to treat diarrhea, aphthae, dysentery and ulcers (Lansky and Newman, 2007). However, not only the commercial cultivars but its wild genotypes had various therapeutic properties. The utilization of wild pomegranate fruits which is also known as daru, is traditionally lies in drying the arils of fruits to prepare a souring product known as anardana used in Ayurvedic and Unani medicines (Devi et al., 2011). Anardana is dried arils from sour wild pomegranate fruits and mainly used as acidulent in Northern Indian styled chutney with various ingredients such as salt, mint, etc., and other culinary preparations in North India as a replacement of acidic amchur (dried green mango powder). The acidic product anardana is also used in preparing digestive candies. The rind or peel of wild pomegranate fruit also has good medicinal value and is used by India's herbal industry on very small scale. However, its conventional uses include preparation of ink for school children to write on Takhti, in dying leather, for making FYM (Murtaza and Ahmad, 2017). Devi et al. (2011) have found wild pomegranate fruits (Daru) are rich in antioxidants, has antibacterial properties and has been found useful in treating dental health. Therefore, ongoing studies should focus on developing new pomegranate derived products to benefit from these constituents throughout a healthy life cycle.

\section{Nutraceutical opportunities/properties}

ROS (Reactive oxygen species) created from interaction with ionizing radiation or xenobiotics during normal cellular metabolic processes are well-recognized concausal factors in many chronic diseases, including cardiovascular diseases and cancer. The lethal effects of ROS might be dependent on their capability to damage appropriate and sensitive biological substrates, such as DNA (deoxyribonucleic acid), RNA (Ribonucleic acid), proteins and membrane lipids and they include various radicals such as superoxide radicals $\left(\mathrm{O}_{2}^{-}\right)$, lipoperoxides, hydrogen peroxide $\left(\mathrm{H}_{2} \mathrm{O}_{2}\right)$ and hydroxyl free radicals $\left(\mathrm{OH}^{-}\right)$. The use of therapeutic agents as anti-oxidative and antiproliferative in the form of phytonutrients and nutraceuticals from various fruits and vegetables had opened a new potential way for protecting, preventing and cure of certain malignancies due to reservoir of natural antioxidants (Ismail et al., 2012). In these way pomegranate and its wild genotypes byproducts plays important role since ancient times due to high pharmacological potential of each parts as used in ayurveda. There are many studies on the reported evidence of health benefits of various pomegranate parts on humans as well as on animals in recent times (Table 4). Aviram et al. (2000) analyzed the effect of pomegranate juice consumption by healthy males in 2 human studies. In the first study aged 20-35 years were supplemented with $50 \mathrm{ml}$ pomegranate juice/day (1.5 mmol total polyphenols) for 2 weeks and in subsequent study, for $\leq 10$ weeks, three subjects were supplemented with increasing doses of pomegranate juice (20-80 ml/day, equivalent to 0.54-2.16 mmol total polyphenols/day). The study shows that juice had strong antiatherogenic effects in healthy males lying on preventive lipoprotein oxidation due to decreased low-density lipoprotein susceptibility toward aggregation as well as retention and improved activity of serum paraoxonase by 20 per cent. The study shows that potent antioxidative capacity of juice against lipid peroxidation may be the innermost link for the antiatherogenic effects of juice on lipoproteins, macrophages and platelets. In another study by Esmaillzadeh et al. (2004) have reported the effect of pomegranate juice (concentrated) intake ( $40 \mathrm{~g}$ ) on lipid profiles of diabetic patients (type II) with hyperlipidemia ( $\geq 200 \mathrm{mg} / \mathrm{dl}$ total cholesterol or triglycerides). After completion of the study (8 weeks) decrease were noticed in total cholesterol level $(5.43 \%)$, low-density lipoprotein cholesterol level $(9.24 \%)$, total/High-density lipoprotein cholesterol proportion $(7.27 \%)$ as well as LDL/HDL proportion (11.76\%). Pomegranate juice has higher content of flavonoids and phenols including tannin which have many health benefits including significant antiatherosclerotic activity. Kaplan et al. (2001) have prepared concentrated pomegranate juice, by squeezing the whole fruit and diluted in water as $6.25 \mathrm{ml}$ of concentrated juice in 1 liter of water. This solution was fed to the mice an average of 5 $\mathrm{ml} /$ day $(0.875 \mathrm{mmol}$ equivalent of total polyphenols $/ \mathrm{d})$. The study revealed that mice with highly developed atherosclerosis pomegranate juice supplementation decreased macrophage oxidative stress, macrophage cholesterol flux furthermore even attenuated the progress of atherosclerosis. Afaq et al. (2005) have reported fruit extract of pomegranate provide clear indication of anti skin tumor-promoting effects in CD-1 mouse due to strong antiinflammatory along with antioxidant properties of the extract 
(anthocyanins, ellagitannins and hydrolyzable tannins). They reported that extract application resulted in a substantial decrease of ODC and cyclooxygenase-2 skin edema, hyperplasia, epidermal ornithine decarboxylase activity and protein expression, which are classic markers of tumor and inflammation promotion. In another study, anti-inflammatory and antioxidant substances prevent the probability of delayed wound healing. In general, various active substances of pomegranate can act as antibacterial, antiinflammatory and have strong antioxidant activity. The increased dosage of standardized extract of pomegranate ( $40 \%$ ellagic acid) ointments shows important effects of collagen formation and 10 per cent this standardized extract ointment is helpful for the healing of second-degree burns in rats (Lukiswanto et al., 2019). Different studies have also reported role of pomegranate extract in preventing as well as reducing pathogenic dental bacteria which leads reduction in the risk of gingivitis, plaque and periodontal disease. Hajifattahi et al. (2016) have reported that pomegranate petal hydroalcoholic extract $(50 \%$ water and $50 \%$ ethanol) had high inhibitory antibacterial effect on very common oral bacteria, such as Streptococcus salivarius, S. sanguinis, S. mutans, S. sobrinus and Enterococcus faecalis. The maximum antibacterial effect observed against $S$. mutans with minimum inhibitory concentration of 3.9 $\mathrm{mg} / \mathrm{ml}$ and showed maximum zone of inhibition zone against $S$. sanguinis and minimum against $E$. faecalis. The bioactive compound in various parts of pomegranate has also shown antiviral properties that modulate respiratory infections and influenza by inhibition of

Table 4: Nutraceutical potential of pomegranate fruit and its by-products extracts

\begin{tabular}{|c|c|c|}
\hline Type/Health status & $\begin{array}{l}\text { Fruit part/Extract used/ } \\
\text { Dose/Time (days) }\end{array}$ & Health effects/Source \\
\hline Humans: Healthy men & $\begin{array}{l}\text { Pomegranate juice (fruit squeezed and } \\
\text { enzymatically treated with pectinase } \\
\text { to yield juice); } 50 \mathrm{ml} / \mathrm{d} \text { for } 14 \mathrm{~d} \text { and } \\
20-80 \mathrm{ml} / \mathrm{d} \text { for }<70 \mathrm{~d} \text {. }\end{array}$ & $\begin{array}{l}\text { Reduced LDL susceptibility to aggregation and retention; } \\
\text { increased activity of serum paraoxonase (esterase which protect } \\
\text { against lipid peroxidation) by } 20 \% \text { (Aviram et al., 2000). }\end{array}$ \\
\hline $\begin{array}{l}\text { Mice: Apolipoprotein E-deficient } \\
\text { with atherosclerosis }\end{array}$ & $\begin{array}{l}\text { Pomegranate juice }(6.25 \mathrm{ml} \\
\text { concentrated juice was diluted in one } \\
\text { litre of water }) ; 5 \mathrm{ml} / \mathrm{d} \text { for } 60 \mathrm{~d} .\end{array}$ & $\begin{array}{l}\text { Reduction in macrophage oxidative stress, macrophage } \\
\text { cholesterol flux and attenuated the development of } \\
\text { atherosclerosis (Kaplan et al., 2001). }\end{array}$ \\
\hline $\begin{array}{l}\text { Humans:Diabetic patients } \\
\text { (Type II) with hyperlipidemia }\end{array}$ & $\begin{array}{l}\text { Concentrated pomegranate juice; } 40 \\
\mathrm{~g} / \mathrm{d} \text { for } 56 \mathrm{~d} \text {. }\end{array}$ & $\begin{array}{l}\text { Decrease in total cholesterol }(5.43 \%) \text {, LDL-cholesterol }(9.24 \%) \text {, } \\
\text { LDL/HDL-cholesterol }(11.76 \%) \text { and total/HDL-cholesterol } \\
(7.27 \%) \text { (Esmaillzadeh et al., 2004). }\end{array}$ \\
\hline $\begin{array}{l}\text { Humans:Diabetic patients } \\
\text { (Type II) }\end{array}$ & $\begin{array}{l}\text { Pomegranate juice (Juice obtained by } \\
\text { squeezing fruits then filteration, } \\
\text { pasteurization, concentration); } 50 \mathrm{ml} / \mathrm{d} \\
\text { for } 90 \mathrm{~d} \text {. }\end{array}$ & $\begin{array}{l}\text { Decreased lipid peroxidation levels and cellular uptake of } \\
\text { oxidized LDL (Rosenblat et al., 2006). }\end{array}$ \\
\hline Humans:Active healthy men & Pomegranate juice; $500 \mathrm{ml} / \mathrm{d}$ for $15 \mathrm{~d}$. & $\begin{array}{l}\text { Potent anti-inflammatory, anti-muscle dammage and anti- } \\
\text { thrombocytopenia. Decreased systolic blood pressure, creatinine } \\
\text { and muscle damage parameters (Achraf et al., 2017). }\end{array}$ \\
\hline Albino Wistar rats: Diabetic & $\begin{array}{l}\text { Aqueous flower extracts }(500 \mathrm{~g} \text { air- } \\
\text { dried flowers powder were extracted } \\
\text { with water in soxhlet for } 6 \mathrm{~h}) ; 250 \\
\mathrm{mg} / \mathrm{kg} / \mathrm{d} \text { for } 21 \mathrm{~d} \text {. }\end{array}$ & $\begin{array}{l}\text { Reduction in total cholesterol, triglycerides, LDL-cholesterol, } \\
\text { Increase: HDL-cholesterol (Bagri et al., 2009). }\end{array}$ \\
\hline Mice: $\mathrm{CD}-1$ mice & $\begin{array}{l}\text { Pomegranate fruit extract (freeze } \\
\text { dried extract of arils squeezed in } 70 \% \\
\text { acetone }(1: 20 \text { by w/v); } 2 \mathrm{mg} \text { for } 48 \mathrm{~h} .\end{array}$ & $\begin{array}{l}\text { Possesses antiskintumor-promoting effects in CD-1 mouse (Afaq } \\
\text { et al., 2005). }\end{array}$ \\
\hline $\begin{array}{l}\text { Humans: Ulcerative colitis } \\
\text { patients }\end{array}$ & $\begin{array}{l}\text { Punica granatum peel aqueous extract } \\
(1 \mathrm{~kg} \text { peel powder mixed/ liter of } \\
\text { boiling water for } 6 \mathrm{~h} \text { and concentrated } \\
\text { to } 100 \mathrm{mg} \text { extract }) ; 6 \mathrm{~g} / \mathrm{d} \text { for } 28 \mathrm{~d} \text {. }\end{array}$ & $\begin{array}{l}\text { Decreased Lichtiger colitis activity index, effective in } \\
\text { complementary management of UC (Kamali et al., 2015). }\end{array}$ \\
\hline $\begin{array}{l}\text { Humans: Women patients with } \\
\text { dyslipidemia }\end{array}$ & $\begin{array}{l}\text { Pomegranate peel extract }(500 \mathrm{mg} \text { dried } \\
80 \% \text { ethanolic extract encapsulated along } \\
\text { with rice flour } 50 \mathrm{mg}) ; 500 \mathrm{mg} / \mathrm{d} \text { for } 56 \mathrm{~d} .\end{array}$ & $\begin{array}{l}\text { Decrease in systolic blood pressure, LDL and total cholesterol; } \\
\text { increase in HDL-cholesterol (Haghighian et al., 2016). }\end{array}$ \\
\hline $\begin{array}{l}\text { Humans: Diabetes mellitus } \\
\text { type- } 2 \text { patients }\end{array}$ & $\begin{array}{l}\text { Pomegranate peel extract (vacuum } \\
\text { oven dried } 70 \% \text { ethanolic extract); } \\
500 \mathrm{mg} / \mathrm{d} \text { for } 56 \mathrm{~d} \text {. }\end{array}$ & $\begin{array}{l}\text { Attenuated the systolic and diastolic blood pressure in type-2 } \\
\text { diabetic patients, hypolipidemic, hypoglycemic, antioxidative } \\
\text { potential (Grabez et al., 2019). }\end{array}$ \\
\hline $\begin{array}{l}\text { Humans: Overweight and obese } \\
\text { patients }\end{array}$ & $\begin{array}{l}\text { Whole pomegranate fruit extract; } \\
1000 \mathrm{mg} / \mathrm{d} \text { for } 30 \mathrm{~d} \text {. }\end{array}$ & $\begin{array}{l}\text { Anti-inflammatory effect; decreases body weight, serum glucose, } \\
\text { total cholesterol, LDL; Increases HDL (Hosseini et al., 2016) }\end{array}$ \\
\hline Male albino rats & $\begin{array}{l}\text { Whole pomegranate fruit extract; } 10 \\
\% \text { (twice/d) for } 14 \mathrm{~d} \text {. }\end{array}$ & $\begin{array}{l}\text { Accelerates the healing of deep second-degree burn wound } \\
\text { (Lukiswanto et al., 2019) }\end{array}$ \\
\hline
\end{tabular}


RNA replication (Ismail et al., 2012). Moradi et al. (2017) have observed anti-influenza A viruses activity of the pomegranate $(70 \%$ ethyl alcohol) extracts by using of MDCK cell line and MTT (3-[4,5-dimethylthiazol- 2-yl]-2,5-diphenyltetrazolium bromide) method. The extract anti-influenza A virus activity could be possibly to its phenolic compounds. The pomegranate extract antiviral activity may be related with the existence of hydrolysable tannins along with polyphenols, specifically punicalagin and gallagic acid (Reddy et al., 2007). In patients with type 2 diabetes mellitus, Grabez et al. (2019) reported the effects of pomegranate peel extract ( $70 \%$ ethanol) intake on plasma lipid profile, fatty acid levels and blood pressure. They reported extract significantly lowered both systolic and diastolic blood pressure. However, plasma levels of triglycerides, low-density lipoprotein cholesterol/high-density lipoprotein cholesterol ratio (LDL-C/HDL-C) were significantly decreased, while the level of HDL-C was increased. Haghighian et al. (2016) have observed a positive effect of pomegranate peel extract (500 mg daily for 8 weeks) consumption in improving cardiovascular risk factors in obese women with dyslipidemia. The most common type of inflammatory bowel diseases is Ulcerative colitis, is characterized by inflammation and ulceration of the mucosal layer of the colon. Kamali et al. (2015) have observed $P$. granatum peel extract seems to be effective in complementary management of ulcerative colitis through consumption of $P$. granatum peel aqueous extract (equivalent to $6 \mathrm{~g}$ of dry peel/day) for four weeks. Hosseini et al. (2016) have observed that pomegranate extract may reduce complications linked with obesity as is great source of antioxidants and when $1000 \mathrm{mg}$ of pomegranate extract supplemented in individuals with obesity and overweight daily for 30 days resulted in a considerable decrease in serum levels of glucose, insulin, total cholesterol, LDL-C and increased HDL-C significantly.

\section{Antibacterial activity}

The pomegranate peel is reported to have several health benefits due to the presence of various constituents like tannins, flavonoids, alkaloids and organic acids (Malviya et al., 2014). The antimicrobial activities of phenolic compounds have involved the multiple modes of action like degradation of cell wall, interaction with the composition and disruption of cytoplasmic membrane, precipitation of membrane proteins resulting in microbial cell lysis (Ismail et al., 2012). The range of antibacterial activity reported in literature has been mentioned in Table 5. Duman et al. (2009) have reported that extract of pomegranate arils show remarkable antibacterial activities against all the tested bacterial strains (Pseudomonas aeruginosa, Staphylococcus aureus, Escherichia coli, Enterococcus faecalis, Rhodotorula rubra, Candida albicans). Devi et al. (2011) have compared antibacterial activity of different parts (peel, white membrane and seeds) of pomegranate with wild pomegranate and reported that all parts showed significant inhibition zone against Streptococcus sp., Lactobacillus sp., Staphylococcus sp., and Proteus sp. Nuamsetti et al. (2012) have reported antibacterial activity against Bacillus subtilis, Staphylococcus aureus, Escherichia coli and Salmonella typhimurium in different extracts (hot water, $95 \%$ ethanol and acetone) of pomegranate peels and arils by agar well-diffusion method. They further reported that Gram-positive bacteria were generally more sensitive to the extracts than Gramnegative ones, as highest inhibition zones were recorded for $E$. coli as $30.3 \mathrm{~mm}$ in acetone extract, followed by ethanol $(29.0 \mathrm{~mm})$ and hot water extract $(27.0 \mathrm{~mm})$, whereas, for $S$. aureus highest inhibition zones as $34.0 \mathrm{~mm}$ in ethanol extract have been observed. Malviya et al. (2014) have tested antibacterial activity of pomegranate peel extracts against four bacterial strains like Staphylococcus aureus, Enterobacter aerogenes, Salmonella typhi, Klebsiella pneumoniae and reported that extracts show remarkable antibacterial activities against all the tested bacterial strains. The antibacterial activity of peel of pomegranate may be due to the presence of broad spectrum antimicrobial compounds that act against both Gram positive and Gram negative bacteria. However, Abdolahi et al. (2018) have reported that flower extract of pomegranate also shows antimicrobial activities against Escherichia coli, Staphylococcus aureus, S. epidermidis, Enterococcus faecalis, Pseudomonas aeruginosa, and Klebsiella pneumonia.

\section{Challenges in utilization and limitations}

Pomegranate fruit arils usually used for table purpose since medial time by peoples. But other parts didn't receive any commercial attention due to difficulty of its astringency because of high tannin content as well polyphenolic compounds. Pomegranate peel is still underutilized in food systems because astringency is the key restrictive factor in its exploitation as food regardless of its exceptional nutritional as well as ethnoparmacological potential. The harsh sensation of pomegranate peel depends on the formation of tannin-salivary protein complexes. Tannins undergo precipitation in the oral cavity as they are exposed to histatins and proline rich proteins. With the production of precipitated tannins and salivary proteins, especially salivary glycoprotein complexes, haze formation is further enhanced (Kallithraka et al., 2001; Dinnella et al., 2009). Despite the complexity of its astringency, however, dietary use of pomegranate peel is increasingly seen as of immense value. By virtue of its nutritional composition, peel could be realistically utilized as a important ingredient in food products (Viuda-Martos et al., 2010) to easily supplied macro as well as micro-nutrients such as minerals, vitamins, $\beta$-carotene, polysaccharides and fibre (Rowayshed et al., 2013; Omer et al., 2019). However, wild pomegranate fruit characteristics totally differs that of commercial pomegranate fruit due to its specific growing conditions as well as in terms of production of highly acidic fruits rich in organic acids which have thick flavedo. Although, it is widely found growing in natural habitat of Himachal Pradesh, Uttarakhand, Jammu and Kashmir, which also lead to wide variation in its fruit characteristics. Due to highly acidic nature of wild pomegranate cannot be used for table purpose and its traditional utilization lies in the dried seeds along with pulp (arils) which is known as anardana. The fresh arils of wild pomegranate contain high level of organic acid (3.88\% as citric acid) (Thakur et al., 2018) and it has been used in Indian traditional chutneys and other dishes as souring agent but its fruits commercial potential yet to be tapped besides anardana production. A number of formulations of anardana have been used as ayurvedic medicines in the treatment of dysentery, diarrhea etc. But at commercial scale wild pomegranate arils powder has not got popularize, because of the sensitivity of powder to oxidation due to the presence of high oil content in the seed portion of arils which shortens its shelf life. Besides this some value added products from arils have been already standardized (Thakur et al., 2017; Thakur et al., 2017a; Thakur et al., 2018a; Thakur et al., 2018b). However, like cultivated pomegranate peel, 
Table 5: Antimicrobial activity of fruit and its by-product extracts by agar well diffusion method against various micro-organisms

\begin{tabular}{|c|c|c|c|}
\hline $\begin{array}{l}\text { Type of fruit/ } \\
\text { Fruit part used }\end{array}$ & Extract preparation & Micro-organism & $\begin{array}{l}\text { Antimicrobial activity } \\
\text { (Inhibition zone } \mathbf{m m} \text { ) }\end{array}$ \\
\hline $\begin{array}{l}\text { Pomegranate } \\
\text { peel }\end{array}$ & $\begin{array}{l}5 \mathrm{~g} \text { powdered peel dissolved in } 80 \% \text { methanol and left in dark } \\
\text { at room temperature for } 1 \mathrm{~h} \text { prior to filtration (Whatman no. } \\
1 \text { ) and centrifugation at } 8654 \mathrm{~g} \text { for } 10 \mathrm{~min} \text { at } 5^{\circ} \mathrm{C} \text {. Then extract } \\
\text { was membrane filtered }(0.45 \mu \mathrm{m}) \text { followed by concentration } \\
\text { under reduced pressure at } 40^{\circ} \mathrm{C} \text {. Dried extract were then } \\
\text { dissolved in } 80 \% \text { methanol }(10 \mathrm{mg} / \mathrm{ml})(\mathrm{Al}-\text { Zoreky, } 2009) \text {. }\end{array}$ & \begin{tabular}{|l} 
Listeria monocytogenes (ATCC 7644) \\
Staphylococcus aureus (MRSA) \\
Bacillus subtilis (ATCC 6633) \\
Escherichia coli (ATCC 10536) \\
Pseudomonas aeruginosa (ATCC 9027) \\
Yersinia enterocolitica (ATCC 23715)
\end{tabular} & $\begin{array}{l}20 \\
16 \\
17 \\
16 \\
18 \\
19\end{array}$ \\
\hline $\begin{array}{l}\text { Pomegranate } \\
\text { (Eksi variety) } \\
\text { arils }\end{array}$ & $\begin{array}{l}\text { Arils of fruits (about } 100 \mathrm{~g} \text { lots) were hand-separated and frozen } \\
\text { at }-20^{\circ} \mathrm{C} \text {. Three replicates were maintained for each analysis, } \\
\text { each replicate composed of six pomegranate fruits. Arils from } \\
\text { each cultivar were thawed at room temperature and then } \\
\text { homogenized in a food processor. Slurries were used to prepare } \\
\text { fruit extracts for antimicrobial activity tests (Duman et al., 2009). }\end{array}$ & $\begin{array}{l}\text { Pseudomonas aeruginosa } \\
\text { Staphylococcus aureus } \\
\text { Escherichia coli } \\
\text { Enterococcus faecalis } \\
\text { Rhodotorula rubra } \\
\text { Candida albicans }\end{array}$ & $\begin{array}{l}20.7 \\
17.7 \\
26.0 \\
15.7 \\
22.0 \\
23.7\end{array}$ \\
\hline $\begin{array}{l}\text { Pomegranate } \\
\text { peel }\end{array}$ & \multirow{3}{*}{$\begin{array}{l}\text { Crude solvent extract was prepared by taking } 50 \mathrm{~g} \text { of dried } \\
\text { powder sample and extracted by Soxhlet distillation } \\
\text { apparatus using methanol. The solvent was removed } \\
\text { under reduced pressure in a rotary evaporator until the } \\
\text { residue become completely dry (Devi et al., 2011). }\end{array}$} & $\begin{array}{l}\text { Streptococcus sp. } \\
\text { Lactobacillus sp. } \\
\text { Staphylococcus } \mathrm{sp} . \\
\text { Proteus } \mathrm{sp} .\end{array}$ & $\begin{array}{l}27 \\
25 \\
25 \\
23\end{array}$ \\
\hline $\begin{array}{l}\text { Pomegranate } \\
\text { white } \\
\text { membrane }\end{array}$ & & $\begin{array}{l}\text { Streptococcus sp. } \\
\text { Lactobacillus } \mathrm{sp} . \\
\text { Staphylococcus } \mathrm{sp} . \\
\text { Proteus } \mathrm{sp} .\end{array}$ & $\begin{array}{l}26 \\
24 \\
25 \\
23\end{array}$ \\
\hline $\begin{array}{l}\text { Pomegranate } \\
\text { seeds }\end{array}$ & & $\begin{array}{l}\text { Streptococcus } \mathrm{sp} . \\
\text { Lactobacillus } \mathrm{sp} . \\
\text { Staphylococcus } \mathrm{sp} . \\
\text { Proteus } \mathrm{sp} .\end{array}$ & $\begin{array}{l}25 \\
24 \\
24 \\
20\end{array}$ \\
\hline $\begin{array}{l}\text { Wild } \\
\text { pomegranate } \\
(\text { Daru }) \text { peel }\end{array}$ & \multirow{3}{*}{$\begin{array}{l}\text { Crude solvent extract was prepared by taking } 50 \mathrm{~g} \text { of dried } \\
\text { powder sample and extracted by Soxhlet distillation } \\
\text { apparatus using methanol. The solvent was removed under } \\
\text { reduced pressure in a rotary evaporator until the residue } \\
\text { become completely dry (Devi et al., 2011). }\end{array}$} & $\begin{array}{l}\text { Streptococcus sp. } \\
\text { Lactobacillus sp. } \\
\text { Staphylococcus sp. } \\
\text { Proteus sp. }\end{array}$ & $\begin{array}{l}28 \\
26 \\
28 \\
24\end{array}$ \\
\hline $\begin{array}{l}\text { Wild } \\
\text { pomegranate } \\
(\text { Daru) white } \\
\text { membrane }\end{array}$ & & $\begin{array}{l}\text { Streptococcus sp. } \\
\text { Lactobacillus } \mathrm{sp} . \\
\text { Staphylococcus } \mathrm{sp} . \\
\text { Proteus } \mathrm{sp} .\end{array}$ & $\begin{array}{l}28 \\
26 \\
27 \\
23\end{array}$ \\
\hline $\begin{array}{l}\text { Wild } \\
\text { pomegranate } \\
(\text { Daru }) \text { seeds }\end{array}$ & & $\begin{array}{l}\text { Streptococcus sp. } \\
\text { Lactobacillus } \mathrm{sp} . \\
\text { Staphylococcus } \mathrm{sp} . \\
\text { Proteus } \mathrm{sp} . \\
\end{array}$ & $\begin{array}{l}25 \\
24 \\
25 \\
22 \\
\end{array}$ \\
\hline $\begin{array}{l}\text { Pomegranate } \\
\text { arils }\end{array}$ & \multirow{2}{*}{$\begin{array}{l}50 \mathrm{~g} \text { of blended peels or arils were mixed with } 100 \mathrm{ml} \text { of } 95 \% \\
\text { ethanol followed by shaking at room temperature for } 18 \mathrm{~h} \text { and } \\
\text { then filtration. The filtrates were concentrated under reduced } \\
\text { pressure with a rotary evaporator at } 40^{\circ} \mathrm{C} \text { and this crude } \\
\text { extract were kept at } 4^{\circ} \mathrm{C} \text { until use (Nuamsetti et al., 2012). }\end{array}$} & $\begin{array}{l}\text { Bacillus subtilis } \\
\text { Staphylococcus aureus } \\
\text { Escherichia coli } \\
\text { Salmonella typhimurium }\end{array}$ & $\begin{array}{l}24.3 \\
20.7 \\
23.7 \\
19.7\end{array}$ \\
\hline $\begin{array}{l}\text { Pomegranate } \\
\text { peel }\end{array}$ & & $\begin{array}{l}\text { Bacillus subtilis } \\
\text { Staphylococcus aureus } \\
\text { Escherichia coli } \\
\text { Salmonella typhimurium }\end{array}$ & $\begin{array}{l}31.0 \\
34.0 \\
29.0 \\
26.3\end{array}$ \\
\hline $\begin{array}{l}\text { Pomegranate } \\
\text { (Ganesh } \\
\text { variety) peel }\end{array}$ & $\begin{array}{l}20 \mathrm{~g} \text { of ground peel soaked in } 100 \mathrm{ml} \text { of methanol in the } \\
\text { shaking incubator }(200 \mathrm{rpm}) \text {, followed by incubation }\left(37^{\circ} \mathrm{C}\right) \\
\text { for } 24 \mathrm{~h} \text {. After filtering extract with Whatman No. } 1 \text { filter } \\
\text { paper, filtrate was stored at } 4^{\circ} \mathrm{C} \text { (Malviya et al., 2014). }\end{array}$ & $\begin{array}{l}\text { Staphylococcus aureus } \\
\text { Enterobacter aerogenes } \\
\text { Salmonella typhi } \\
\text { Klebsiella pneumoniae }\end{array}$ & $\begin{array}{l}24.5 \\
18.2 \\
18.3 \\
11.3\end{array}$ \\
\hline $\begin{array}{l}\text { Pomegranate } \\
\text { flower }\end{array}$ & $\begin{array}{l}\text { The powdered flowers }(10 \mathrm{~g}) \text { were mixed with } 100 \mathrm{ml} \text { of } \\
\text { the ethanol }(70 \%) \text { followed by shaking in rotary } \\
(200 \mathrm{rpm} \text { for } 24 \mathrm{~h}) \text { at room temperature. After extract } \\
\text { filteration with Whatman No. } 1 \text { filter paper, filtrate was } \\
\text { evaporated to dryness at } 40^{\circ} \mathrm{C} \text { in a rotary evaporator and } \\
\text { then the extract was freeze-dried (Abdolahi et al., 2018). }\end{array}$ & $\begin{array}{l}\text { Escherichia coli } \\
\text { Staphylococcus aureus } \\
\text { Staphylococcus epidermidis } \\
\text { Enterococcus faecalis } \\
\text { Pseudomonas aeruginosa } \\
\text { Klebsiella pneumonia }\end{array}$ & $\begin{array}{c}10 \\
13 \\
19 \\
11 \\
8 \\
11\end{array}$ \\
\hline
\end{tabular}


wild pomegranate peel has also unique astringent taste which is rich source of phenolic and fibre besides minerals. Astringency is the major limiting factor due to which its commercial value is not tapped yet, besides its small scale use by Indian herbal industry. Extract of pomegranate peel can generate toxicity when supplemented excessively above threshold limits. As there are many antinutrients factors in plants based foods which directly or indirectly shows adverse effects on nutrients bioavailability when consumed in excess, but adequate processing methods may lead to reduction in their content before consumption (Hamid et al., 2017). As the use of peel from pomegranate and its extracts for functional and nutraceutical (enrichment/fortification) purposes in food products is on the rise, the toxicological issues deserves the utmost consideration.

\section{Conclusion}

Based on research on various therapeutic properties over the last decade on different parts of pomegranate and clinical trials, it seems to be a promising food with well-defined remedial benefits. The antioxidant capacity of pomegranate and its parts are linked to the presence of bioactive compounds, such as phenolic compounds. The bioactive compounds associated with pomegranate and its fruit parts such as phenolic acids (gallic acid), flavonoids (anthocyanins) and tannins may possess a strong tools for protective and possibly therapeutic interventions against various human diseases. In addition to that, the possible use of pomegranate extracts as a therapy or adjunct for the prevention and treatment of several disease processes, such as diabetes, cardiovascular disease, atherosclerosis, inflammation, microbial infection, obesity, male infertility, Alzheimer underscores the need for more clinical research. Therefore, current studies should focus on developing novel pomegranate derived products utilizing it's all parts to gain from these bioactive constituents throughout a healthy life cycle.

\section{Conflict of interest}

The authors declare that there are no conflicts of interest in the course of conducting the research. All the authors had final decision regarding the manuscript and decision to submit the findings for publication.

\section{References}

Abdolahi, N.; Soltani, A.; Mirzaali, A.; Soltani, S.; Balakheyli, H. and Aghaei, M. (2018). Antibacterial and antioxidant activities and phytochemical properties of Punica granatum flowers in Iran. Iran J. Sci. Technol. Trans. Sci., https://doi.org/10.1007/s40995-017-0413-8.

Achraf, A.; Hamdi, C.; Turki, M.; Abdelkarim, O.; Ayadi, F.; Hoekelmann, A.; Yaich, S. and Souissi, N. (2017). Natural pomegranate juice reduces inflammation, muscle damage and increase platelets blood levels in active healthy Tunisian aged men. Alexandria Journal of Medicine, http://dx.doi.org/10.1016/j.ajme.2017.03.005.

Afaq, F.; Saleem, M.; Krueger, C. G.; Reed, J. D. and Mukhtar, H. (2005). Anthocyanin and hydrolyzable tannin-rich pomegranate fruit extract modulates MAPK and NF-kappa B pathways and inhibits skin tumorigenesis in CD-1 mice. Int. J. Cancer, 113:423-433.-vol

Akhavan, H.; Barzegar, M.; Weidlich, H. and Zimmermann, B. F. (2015). Phenolic compounds and antioxidant activity of juices from ten Iranian pomegranate cultivars depend on extraction. Journal of Chemistry, doi: http://dx.doi.org/10.1155/2015/907101.
Ali, S. I.; El-Bazl, F. K.; El-Emary, G.A.E.; Ekhlaque, A. and Mohamed, A. A. (2014). HPLC-analysis of polyphenolic compounds and free radical scavenging activity of pomegranate fruit (Punica granatum L.). International Journal of Pharmaceutical and Clinical Research, 6:348-355.

Aloqbi, A.; Omar, U.; Yousr, M.; Grace, M.; Lila, M. A. and Howell, N. (2016). Antioxidant activity of pomegranate juice and punicalagin. Natural Science, 8:235-246.

Al-Rawahi, A. S.; Rahman, M. S.; Guizani, N. and Essa, M. M. (2013). Chemical composition, water sorption isotherm and phenolic contents in fresh and dried pomegranate peels. Drying Technology, 31:257-263.

Al-Zoreky, N. S. (2009). Antimicrobial activity of pomegranate (Punica granatum L.) fruit peels. International Journal of Food Microbiology, 134:244-248.

Ambigaipalan, P.; Camargo, A. C. and Shahidi, F. (2016). Phenolic compounds of pomegranate byproducts (outer skin, mesocarp, divider membrane) and their antioxidant activities. Journal of Agricultural and Food Chemistry, 64:6584-6604.

Anahita, A.; Asmah, R. and Fauziah, O. (2015). Evaluation of total phenolic content, total antioxidant activity and antioxidant vitamin composition of pomegranate seed and juice. General Medicine, 3:1-4.

Ardekani, M.R.S.; Hajimahmoodi, M.; Oveisi, M. R.; Sadeghi, N.; Jannat, B.; Ranjbar, A. M.; Gholam, N. and Moridi, T. (2011). Comparative antioxidant activity and total flavonoid content of Persian pomegranate (Punica granatum L.) cultivars. Iranian Journal of Pharmaceutical Research, 10:519-524.

Asadi-Gharneh, H. A.; Mohammadzamani, M. and Karimi, S. (2017). Evaluation of physicochemical properties and bioactive compounds of some Iranian pomegranate cultivars. International Journal of Fruit Science, 17:175-187.

Aviram, M.; Dornfeld, L.; Rosenblat, M.; Volkova, N.; Kaplan, M.; Coleman, R.; Hayek, T.; Presser, D. and Fuhrman, B. (2000). Pomegranate juice consumption reduces oxidative stress, atherogenic modifications to LDL, and platelet aggregation: studies in humans and in atherosclerotic apolipoprotein E-deficient mice. Am. J. Clinl. Nutr., 71:1062-1076.

Bagri, P.; Ali, M.; Aeri, V.; Bhowmik, M. and Sultana, S. (2009). Antidiabetic effect of Punica granatum flowers: Effect on hyperlipidemia, pancreatic cells, lipid peroxidation and antioxidant enzymes in experimental diabetes. Food Chem. Toxicol., 47:50-54.

Barros, Z. M. P.; Salgado, J. M. and Melo, P. S. (2014). Enrichment of commercially-prepared juice with pomegranate (Punica granatum L.) peel extract as a source of antioxidants. Journal of Food Research, 3:179-187.

Basiri, S. (2015). Evaluation of antioxidant and antiradical properties of pomegranate (Punica granatum L.) seed and defatted seed extracts. Journal of Food Science and Technology, 52:1117-1123.

Benzie, I. F. and Strain, J. J. (1996). Ferric reducing ability of plasma (FRAP) as a measure of antioxidant power: the FRAP assay. Analytical Biochemistry, 239:70-76.

Croft, K. D. (2006). Dietary polyphenols: Antioxidant or not?. Archives of Biochemistry and Biophysics, 595:120-125.

Das, K. and Gezici, S. (2018). Plant secondary metabolites, their separation, identification and role in human disease prevention. Ann. of Phytomed., 7(2):13-24.

Derakhshan, Z.; Ferrante, M.; Tadi, M.; Ansari, F.; Heydari, A.; Hosseini, M. S.; Conti, G. O. and Sadrabad, E. K. (2018). Antioxidant activity and total phenolic content of ethanolic extract of pomegranate peels, juice and seeds. Food and Chemical Toxicology, 114:108-111. 
Devi, A.; Singh, V. and Bhatt, A. B. (2011). Comparative antibacterial study of different extract of pomegranate and its wild variety. International Journal of Pharmaceutical Sciences and Research, 2:2647-2650.

Dinnella, C.; Recchia, A.; Fia, G.; Bertucciolo, M. and Monteleone, E. (2009). Saliva characteristics and individual sensitivity to phenolic astringent stimuli. Chemical Senses, 34:295-304.

Duman, A. D.; Ozgen, M.; Dayisoylu, K.S.; Erbil, N. and Durgac, K. (2009). Antimicrobial activity of six pomegranate (Punica granatum 1.) varieties and their relation to some of their pomological and phytonutrient characteristics. Molecules, 14:1808-1817.

Esmaillzadeh, A.; Tahbaz, F.; Gaieni, I.; Alavi-Majd, H. and Azadbakht, L. (2004). Concentrated pomegranate juice improves lipid profiles in diabetic patients with hyperlipidemia. J. Medic. Food, 7:305-308.

Fernandes, L.; Pereira, J. A. C.; Lopez-Cortes, I.; Salazar, D. M. and Ramalhosa, E. C. D. (2015). Physicochemical changes and antioxidant activity of juice, skin, pellicle and seed of pomegranate (cv. mollar de elche) at different stages of ripening. Food Technology and Biotechnology, 53:397-406.

Gill, M. I.; Tomas Barberan, F. A.; Hess Peirce, B.; Holcroft, D. M. and Kader, A. A. (2000). Antioxidant activity of pomegranate juice and its relationship with phenolic composition and processing. Journal of Agricultural and Food Chemistry, 48:4581-4589.

Grabez, M.; Skrbic, R.; Stojiljkovic, M. P.; Rudic-Grujic, V.; Paunovic, M.; Arsic, A.; Petrovic, S.; Vucic, V.; Mirjanic-Azaric, B.; Savikin, K.; Menkovic, N.; Jankovic, T. and Vasiljevic, N. (2019). Beneficial effects of pomegranate peel extract on plasma lipid profile, fatty acids levels and blood pressure in patients with diabetes mellitus type-2: A randomized, double-blind, placebo-controlled study. Journal of Functional Foods, https://doi.org/10.1016/j.jff.2019.103692

Guo, C.; Yang, J.; Wei, J.; Li, Y.; Xu, J. and Jiang, Y. (2003). Antioxidant activities of peel, pulp and seed fractions of common fruits as determined by FRAP assay. Nutrition Research, 23:1719-1726.

Gupta, D. (2015). Methods for determination of antioxidant capacity: a review. International Journal of Pharmaceutical Sciences and Research, 6:546-566.

Haghighian, M. K.; Rafraf, M.; Moghaddam, A.; Hemmati, S.; Jafarabadi, M. A. and Gargari, B. P. (2016). Pomegranate (Punica granatum L.) peel hydro alcoholic extract ameliorates cardiovascular risk factors in obese women with dyslipidemia: A double blind, randomized, placebo controlled pilot study. European Journal of Integrative Medicine, http://dx.doi.org/10.1016/j.eujim.2016.06.010.

Hajifattahi, F.; Moravej-Salehi, E.; Taheri, M.; Mahboubi, A. and Kamalinejad, M. (2016). Antibacterial effect of hydroalcoholic extract of Punica granatum Linn. petal on common oral microorganisms. International Journal of Biomaterials, http://dx.doi.org/10.1155/2016/8098943.

Hajimahmoodi, M.; Oveisi, M. R.; Sadeghi, N.; Jannat, B. and Hadjibabaie, M. (2008). Antioxidant properties of peel and pulp hydro extract in ten Persian pomegranate cultivars. Pakistan Journal of Biological Sciences, 11:1600-1604.

Hamid.; Thakur, N. S. and Kumar, P. (2017). Anti-nutritional factors, their adverse effects and need for adequate processing to reduce them in food. Agric. International, 4(1):56-60.

Hosseini, B.; Saedisomeolia, A.; Wood, L.G.; Yaseri, M. and Tavasoli, S. (2016). Effects of pomegranate extract supplementation on inflammation in overweight and obese individuals: A randomized controlled clinical trial. Complementary Therapies in Clinical Practice, 22:44-50

Hota, M. and Dahiya, D.S. (2017). Physico-chemical properties of some varieties of pomegranate (Punica granatum L.). International Journal of Pure and Applied Bioscience, 5:979-983.
Ismail, T.; Sestili, P. and Akhtar, S. (2012). Pomegranate peel and fruit extracts: A review of potential anti-inflammatory and antiinfective effects. Journal of Ethnopharmacology, 143:397-405.

Kallithraka, S.; Bakker, J.; Clifford, M. N. and Vallis, L. (2001). Correlation between saliva protein composition and some T-I parameters of astringency. Food Quality and Preference, 12:145-152.

Kamali, M.; Tavakoli, H.; Khodadoost, M.; Daghaghzadeh, H.; Kamalinejad, M.; Gachkar, L.; Mansourian, M. and Adibi, P. (2015). Efficacy of the Punica granatum peels aqueous extract for symptom management in ulcerative colitis patients. A randomized, placebo controlled, clinical trial. Complementary Therapies in Clinical Practice, 21:141-146.

Kaplan, M.; Hayek, T.; Raz, A.; Coleman, R.; Dornfeld, L.; Vaya, J. and Aviram, M. (2001). Pomegranate juice supplementation to atherosclerotic mice reduces macrophage lipid peroxidation, cellular cholesterol accumulation and development of atherosclerosis. The Journal of Nutrition, 131(8):2082-2089.

Kulkarni, A. P. (2005). Bioactive molecules from pomegranate fruit waste (pith and carpellary membrane). Ph.D Thesis. Department of fruit and Vegetable Technology, Central Food Technological Research Institute, Mysore, India, pp:213.

Lansky, E. P. and Newman, R. A. (2007). Punica granatum (pomegranate) and its potential for prevention and treatment of inflammation and cancer. Journal of Ethnopharmacology, 109:177-206.

Li, R.; Chen, X. G.; Jia, K.; Liu, Z. P. and Peng, H. Y. (2016). A systematic determination of polyphenols constituents and cytotoxic ability in fruit parts of pomegranates derived from five Chinese cultivars. Springer Plus, 5:1-9.

Li, X.; Wasila, H.; Liu, L.; Yuan, T.; Gao, Z.; Zhao, B. and Ahmad, I. (2015). Physicochemical characteristics, polyphenol compositions and antioxidant potential of pomegranate juices from ten Chinese cultivars and the environmental factors analysis. Food Chemistry, 175:575-584.

Li, Y.; Guo, C.; Yang, J.; Wei, J.; Xu, J. and Cheng, S. (2006). Evaluation of antioxidant properties of pomegranate peel extract in comparison with pomegranate pulp extract. Food Chem., 96(2):254-260.

Lukiswanto, B. S.; Miranti, A.; Sudjarwo, S. A.; Primarizky, H. and Yuniarti, W. M. (2019). Evaluation of wound healing potential of pomegranate (Punica granatum) whole fruit extract on skin burn wound in rats (Rattus norvegicus). J. Adv. Vet. Anim. Res., 6(2):202-207.

Malviya, S.; Jha, A. and Hettiarachchy, N. (2014). Antioxidant and antibacterial potential of pomegranate peel extracts. Journal of Food Science and Technology, 51:4132-4137.

Manach, C.; Scalbert, A.; Morand, C.; Remesy, C. and Jimenez, L. (2004). Polyphenols: food sources and bioavailability. Am. J. Clin. Nutr., 79:727-747.

Mansour, E.; Khaled, A. B.; Lachiheb, B.; Abid, M.; Bachar, K. and Ferchichi, A. (2013). Phenolic compounds, antioxidant, and antibacterial activities of peel extract from Tunisian pomegranate. Journal of Agricultural Science and Technology, 15:1393-1403.

Moradi, M. T.; Karimi, A.; Lorigooini, Z.; Pourgheysari, B.; Alidadi, S. and Hashemi, L. (2017). In vitro Anti influenza virus activity, antioxidant potential and total phenolic content of twelve Iranian medicinal plants. Marmara Pharm. J., 21(4):843-851.

Mphahlele, R. R.; Fawole, O. A.; Stander, M. A. and Opara, U. L. (2014). Preharvest and postharvest factors influencing bioactive compounds in pomegranate (Punica granatum L.): A review. Scientia Horticulturae, 178:114-123.

Murtaza, M. S. and Ahmad, G. S. (2017). Anardana (dehydrated wild pomegranate arils) as livelihood option for rural communities in Chenab valley of Jammu and Kashmir. Indian Journal of Horticulture, 74:306-309. 
Nooreen, Z.; Rai, V. K. and Yadav, N. P. (2018). Phytopharmaceuticals: A new class of drug in India. Ann. of Phytome., 7(1):27-37.

Nuamsetti, T.; Dechayuenyong, P. and Tantipaibulvut, S. (2012). Antibacterial activity of pomegranate fruit peels and arils. Science Asia, 38:319-322.

Omer, H. A. A.; Abdel-Magid, S. S. and Awadalla, I. M. (2019). Nutritional and chemical evaluation of dried pomegranate (Punica granatum L.) peels and studying the impact of level of inclusion in ration formulation on productive performance of growing Ossimi lambs. Bulletin of the National Research Centre, 43:182.

Orak, H. H.; Yagar, H. and Isbilir, S. S. (2012). Comparison of antioxidant activities of juice, peel and seed of pomegranate (Punica granatum L.) and inter-relationships with total phenolic, tannin, anthocyanin and flavonoid contents. Food Science and Biotechnology, 21:373-387.

Pande, G. and Akoh, C.C. (2009). Antioxidant capacity and lipid characterization of six Georgia-grown pomegranate cultivars. Journal of Agricultural Food Chemistry, 57:9427-9436.

Prior, R. L.; Wu, X. and Schaich, K. (2005). Standardized methods for the determination of antioxidant capacity and phenolics in foods and dietary supplements. Journal of Agricultural and Food Chemistry, 53:4290-4302.

Reddy, M. K.; Gupta, S. K.; Jacob, M. R.; Khan, S. I. and Ferreira, D. (2007). Antioxidant, antimalarial and antimicrobial activities of tannin-rich fractions, ellagitannins and phenolic acids from Punica granatum L. Planta Med., 73:461-467.

Rosenblat, M.; Hayek, T. and Aviram, M. (2006). Antioxidative effects of pomegranate juice (PJ) consumption by diabetic patients on serum and on macrophages. Atherosclerosis, 187:363-371.

Rowayshed, G.; Salama, A.; Fadl, M. A.; Hamza, S. A. and Emad, A. M. (2013). Nutritional and chemical evaluation for pomegranate (Punica granatum L.) fruit peel and seeds powders by products. Middle East Journal of Applied Sciences, 3:169-179.

Scalbert, A.; Johnson, I. T. and Saltmarsh, M. (2005). Polyphenols: antioxidants and beyond. The American Journal of Clinical Nutrition, 81:215-217.

Shiban, M. S.; AI-Otaibi, M. M. and AI-Zoreky, N. S. (2012). Antioxidant activity in pomegranate (Punica granatum L.) fruit peels. Food and Nutrition Sciences, 3:991-996.

Sorour, M. A.; Rizk, A. E. and Elsheikh, D. M. (2014). Drying of pomegranate wastes. International Journal of Advanced Technology in Engineering and Science, 2:265-275.
Thakur, A.; Thakur, N. S.; Hamid. and Kumar, P. (2018). Studies on physicochemical and antioxidant properties of wild pomegranate fruits in different locations of Himachal Pradesh, India. International Journal of Current Microbiology and Applied Sciences, 7:2842-2850.

Thakur, N. S.; Dhaygude, G. S. and Gupta, A. (2011). Physico-chemical characteristics of wild pomegranate fruits in different location of Himachal Pradesh. International Journal of Farm Science, 1:37-44.

Thakur, N. S.; Dhaygude, G. S.; and Sharma, A. (2017). Development of cultivated and wild pomegranate mixed fruit jelly and its quality evaluation during storage. Journal of Applied and Natural Science, 9(1):587-592.

Thakur, N. S.; Dhaygude, G. S.; Hamid. and Kumar, P. (2017a). Studies on development and storage quality of appetizer from wild pomegranate (Punica granatum L.) Fruits. Indian Journal of Ecology, 44(6):697-703.

Thakur, N. S.; Dhaygude, G. S.; Thakur, A.; Hamid. and Kumar, P. (2018a). Preparation and storage potentiality of chutney from wild pomegranate (Punica granatum L.) fruits. Journal of Pharmacognosy and Phytochemistry, 7(1):2749-2753.

Thakur, N. S.; Dhaygude, G. S.; Thakur, A.; Kumar, P. and Hamid. (2018b). Studies on Preparation and Preservation of Squash from Wild Pomegranate (Punica granatum L.) Fruits and its Quality Evaluation during Storage. International Journal of Bio-resource and Stress Management, 9(1):007-012.

USDA. (2020). United States Department of Agriculture, Agricultural Research Service, Pomegranates, raw, Pomegranates, juice 100\% National Agricultural Library. USDA. Available online: https:// fdc.nal.usda.gov/fdcapp.html\#/?query=pomegranate (accessed on 17 March 2020).

Viuda-Martos, M.; Fernandez-Lopez, J. and Perez-Alvarez, J. A. (2010). Pomegranate and its many functional components as related to human health: A review. Comprehensive Reviews in Food Science and Food Safety, 9:635-647.

Wani, I. A.; Bhat, M. Y.; Ganai, S. A.; Lone, A. A.; Jan, A. and Mir, M. M. (2014). Variability in wild pomegranate (Punica granatum L.) population from Ganderbal and Budgam districts of Kashmir valley. Indian Journal of Science and Technology, 7:1471-1474.

Zaouay, F.; Mena, P.; Garcia-Viguera, C. and Mars, M. (2012). Antioxidant activity and physico-chemical properties of Tunisian grown pomegranate (Punica granatum L.) cultivars. Industrial Crops and Products, 40:81-89. 